IZA DP No. 4666

Time to Work or Time to Play: The Effect of Student Employment on Homework, Sleep, and Screen Time

Charlene Marie Kalenkoski

Sabrina Wulff Pabilonia

December 2009 


\title{
Time to Work or Time to Play: The Effect of Student Employment on Homework, Sleep, and Screen Time
}

\author{
Charlene Marie Kalenkoski \\ Ohio University \\ and IZA \\ Sabrina Wulff Pabilonia \\ U.S. Bureau of Labor Statistics
}

\section{Discussion Paper No. 4666 \\ December 2009}

\author{
IZA \\ P.O. Box 7240 \\ 53072 Bonn \\ Germany \\ Phone: +49-228-3894-0 \\ Fax: +49-228-3894-180 \\ E-mail: iza@iza.org
}

\begin{abstract}
Any opinions expressed here are those of the author(s) and not those of IZA. Research published in this series may include views on policy, but the institute itself takes no institutional policy positions.

The Institute for the Study of Labor (IZA) in Bonn is a local and virtual international research center and a place of communication between science, politics and business. IZA is an independent nonprofit organization supported by Deutsche Post Foundation. The center is associated with the University of Bonn and offers a stimulating research environment through its international network, workshops and conferences, data service, project support, research visits and doctoral program. IZA engages in (i) original and internationally competitive research in all fields of labor economics, (ii) development of policy concepts, and (iii) dissemination of research results and concepts to the interested public.
\end{abstract}

IZA Discussion Papers often represent preliminary work and are circulated to encourage discussion. Citation of such a paper should account for its provisional character. A revised version may be available directly from the author. 
IZA Discussion Paper No. 4666

December 2009

\section{ABSTRACT}

\section{Time to Work or Time to Play: The Effect of Student Employment on Homework, Sleep, and Screen Time}

We use detailed time-diary information on high school students' daily activities from the 20032008 American Time Use Surveys (ATUS) to investigate the effects of employment on the time a student spends on homework and other major activities. Time-diary data are more detailed and accurate than data derived from responses to 'usual activity' survey questions underlying other analyses and capture the immediate effects of working that may well accumulate over time to affect future outcomes. Our results suggest that employment decreases the time that high school students spend on human-capital-building activities such as homework and extracurricular activities, but also decreases screen time, which may be considered unproductive time. Results for sleep suggest that working teens may not suffer from reduced sleep time.

JEL Classification: J13, J22, J24

Keywords: teenagers, employment, high school, time allocation

Corresponding author:

Charlene Marie Kalenkoski

Ohio University

Department of Economics

Bentley Annex 351

Athens, OH 45701

USA

E-mail: kalenkos@ohio.edu

\footnotetext{
*All views expressed in this paper are those of the authors and do not necessarily reflect the views or policies of the U.S. Bureau of Labor Statistics. The authors would like to thank Bhavna Batra, Yi He, Anna Voynova, and Heath Wiseman for research assistance and Dorinda Allard, Suzanne Bianchi, Harley Frazis, Marianne Janes, David Ribar, Larry Rosenblum, Donna Rothstein, Jay Stewart, Anne Winkler, and Cindy Zoghi for comments.
} 


\section{Introduction}

Many studies have investigated the effects of working while in school on students’ outcomes. On the one hand, working while in high school may provide valuable work experience. Stephenson (1981), Michael and Tuma (1984), Ruhm (1995, 1997), Light (1999, 2001), and Neumark and Joyce (2001) have all found positive effects of student work on future labor market outcomes. Hotz et al. (2002), however, found no effect of high school employment on men's future wages when they controlled for individual-specific unobserved heterogeneity. On the other hand, some researchers have documented a small negative relationship between working while in high school and a student's academic achievement, which may negatively affect future earnings. For example, Ruhm (1995, 1997) and Tyler (2003) found that student employment has a negative effect on both the number of years of schooling that students complete and their 12th grade math achievement. Oettinger (1999) found a decline in the grades of minority students who work long hours. Dustmann and Van Soest (2007) found that part-time work has a small negative effect on males’ exam performance. Warren et al. (2001) and Rothstein (2007), however, found that employment has no effect on students’ grades.

A limitation of all of these studies, however, is that they examine only the associations between work and broad outcomes such as high school completion, overall GPA, or future earnings. They do not examine the underlying mechanisms for these associations. One potential mechanism is that work reduces students' homework time or sleep and thus negatively affects their grades. Recently, Kalenkoski and Pabilonia (2009a) found that students who work more hours on a particular day spend less time on homework on the same day. This is important because there are economic studies that examine the relationship between the time high school students spend on homework and their subsequent math achievement. Using the Longitudinal 
Study of American Youth, Betts (1997) found that an extra half hour per night of assigned homework in grades 7 through 11 raises students' math scores by two full grade levels. Using the National Educational Longitudinal Study of 1988 (NELS:88), Aksoy and Link (2000) and Eren and Henderson (2008) found that additional homework (whether reported or assigned) increases tenth grade math test scores. ${ }^{1}$

Recent research by psychologists on first-year college students found that those who sleep less on school nights (41 minutes on average) have a 0.3 lower grade point averages (GPA) (Peszka et al. 2009). A study by sociologists Brint and Cantwell (2008) found that an extra hour of sleep per week is associated with a 0.06 point increase in college students’ GPA. In addition to affecting homework and sleep, employment might also reduce students' screen time, which may be viewed to be unproductive time. Brint and Cantwell (2008) found that an extra hour spent by college students on computers for fun is associated with a 0.05 decrease in GPA.

In this paper, we use detailed time-diary information on high school students' daily activities from the 2003-2008 American Time Use Surveys (ATUS) to investigate the effects of student employment on the time a student spends on homework and other major activities on the

\footnotetext{
${ }^{1}$ There also have been a couple of excellent studies on college students by Stinebrickner and Stinebrickner (2004, 2008), which examined the effects of study time collected from time diaries on overall grades. In their 2004 study, they found that an increase in first-year college students’ study time from 1 to 2 hours per weekday was associated with a 0.397 increase in their GPAs. In their more recent work (2008), they found that an increase in study time of one hour per day increased students’ GPAs by an amount equivalent to a 5.21 point increase in their ACT scores.
} 
diary day. ${ }^{2}$ Time-diary data are more detailed and accurate than data derived from responses to "usual activity” survey questions underlying previous analyses (Juster 1995). In addition, they capture the immediate effects of working that may well accumulate over time to affect future outcomes.

To analyze these data we take a multiple-equations approach to modeling teen's activities that accounts for the joint determination of the time teens spend in various activities, including employment. Our results suggest that employment decreases the time high school students spend on human-capital-building activities such as homework and extra-curricular activities, but it also decreases screen time. Employment increases the time students spend sleeping on school days but decreases it on non-school days. Results for sleep suggest that, on average, working teens may still get the recommended amount of sleep over the course of the day.

\section{Data}

\footnotetext{
${ }^{2}$ We focus on high school students rather than college students because the ATUS is not representative of the college student population. There are several reasons for this. First, the ATUS is drawn from the Current Population Survey (CPS), a household survey that follows individuals over time at the same household address. If a household member leaves a sampled household to move into a dorm between surveys, then she/he would not be sampled after the move. In addition, although the CPS does sample student dormitories, most students would be considered as having a 'usual residence elsewhere’ (i.e., their parents' households), and thus ATUS interviewers would unsuccessfully attempt to contact college students living in dorms at their parents' residence.
} 
Our primary data source is the pooled 2003-2008 ATUS. The ATUS is a nationally representative survey of the U.S. civilian non-institutionalized population aged 15 years and over. Each person selected for the ATUS is randomly drawn from a sample of households in the Current Population Survey (CPS) that have finished their final CPS interview. The key feature of the ATUS is its 24-hour time diary in which the respondent describes how he or she spends his or her time from 4 A.M. on the day before the interview to 4 A.M. on the day of the interview. Although in reality teens may be engaging simultaneously in multiple activities, the ATUS records only time spent in the primary activity for most activities. ${ }^{3}$ The survey also collects household roster and demographic information and is matched to the CPS household data. One of the advantages of using time diary data compared to other survey data, such as the NLSY97, is that time-diary data are less sensitive to the recall and aggregation bias that is associated with broader survey questions capturing average time spent (Bianchi et al. 2006). They are less susceptible to recall bias because respondents only have to recall the previous day's activities, not the activities of the previous week. They are less susceptible to aggregation bias because respondents report all activities sequentially and thus account for the full 1440 minutes in the day. The NLSY97 does not require the respondent to ensure a time constraint. We examine a subsample of the ATUS respondents who were aged 15-18 on their diary day, attended high school, were interviewed during the typical school year (September through May), were not married or living with a partner, and did not have children of their own living in their households. From this subsample, we excluded low quality diaries (those missing more than 60 minutes of time) and diaries that captured atypical days (those where teens reported either sleeping more than 20 hours or being sick for more than four hours on their diary day)

\footnotetext{
3 The exceptions are secondary child care and, in 2006 and 2007, time spent eating and drinking.
} 
(Juster 1985). These latter restrictions excluded less than half a percent of school-year diaries, leaving us with a sample of 3,027 teenagers.

Our key variables of interest measure whether or not the teen was employed during the week ending with the diary day, whether the individual worked on his/her diary day, and minutes spent on homework, sleeping, and watching TV or using the computer for leisure except for video games (we refer to the latter time throughout the paper as screen time) on the diary day. ${ }^{4}$ We also perform sensitivity analyses where we add time spent on other potentially human-capital building activities, such as schooling-related extracurricular activities and sports, to homework time because previous researchers (Kuhn and Weinberger 2005; Barron, Ewing, and Waddell 2000; Persico, Postlewaite, and Silverman 2004) have shown that those who participate in extracurricular activities and/or high school sports later earn higher wages. Barron, Ewing and Waddell (2000) found that athletic participation increases wages over and above participation in other extracurricular activities, suggesting that the positive association between sports and wages may arise because athletic participation builds teamwork and discipline, skills that are rewarded in the labor market. In addition, Lipscomb (2007) found that participation in extracurricular activities and sports increases students' math and science scores, independent of unobserved individual ability. Our measure of sports participation includes team sport participation, but we are unable to separate this type of participation from other exercise.

We also examine an alternative sleep category that includes all sleep occurring after 7 P.M. on the diary day until the student awakes the following morning. We do this because of the way sleep time is collected in the time diary. Because the 24-hour diary covers activities starting

\footnotetext{
${ }^{4}$ See the Data Appendix for additional details on the specific ATUS codes included in each of our activity categories.
} 
at 4 A.M. on the diary day until 4 A.M. on the next day, the primary daily sleep measure we use includes portions of each of two calendar days’ sleep episodes. However, the ATUS also collects the end time of the activity that was being performed at 4 A.M. on the second day. Thus, we are able to use this to construct a nighttime sleep measure that counts sleep that occurs after all of the diary day's other activities. ${ }^{5}$

Finally, we add game time to our screen time definition. The ATUS game category groups board games and computer and video games together. Therefore it is not possible to distinguish between them. Therefore, we add all time spent in this category to our screen time measure as we suspect that most gaming by teens is done electronically. Note that our homework, sleep, and screen time variables (including alternative definitions) do not account for all of a teen's uses of time but that they do examine the major leisure and human-capital-building activities that account for a substantial portion of their out-of-classroom time. We do not analyze in-classroom time because such time is not discretionary.

For each of our time use variables, Table 1 reports the percentage of respondents who do not participate in key activities. The majority of the students (67\%) were not employed in the previous week. More than half of all students reported not working (86\%) or doing homework (56\%) on their diary day. If we broaden the homework category to include extracurricular activities, $53 \%$ of the students do not participate, and if we also add sports, $37 \%$ of students do not participate. A smaller number reported no screen time (20\%), 16\% if we include games. All students reported sleeping. We also break down these participation numbers by whether the

\footnotetext{
${ }^{5}$ We exclude six diaries where the sleep episode was recorded as ending at 4 A.M. because it was likely due to interviewer error in ending the diary recall early.
} 
diary day was a school day or a non-school day. We define school days as weekdays that are not major holidays. In addition, school days do not include the day after Thanksgiving, Good Friday, or the weekdays between Christmas and New Year's Day because these days are typically school holidays. None of the students in our sample attended class on these days. We do separate analyses by school day and non-school day because school homework assignments and extracurricular activity offerings, as well as state regulations regarding student employment, differ for school days and non-school days. ${ }^{6}$

Comparing participation in these activities across school days and non-school days, we observe that homework participation, on average, is not only statistically significantly different across day types but also largely substantively different. Screen time is also statistically significantly different.

Other surveys provide evidence for the extent of non-participation in some of these activities. For example, in the October 2006 CPS, about 69 percent of high school students were not employed in the reference week (Bureau of Labor Statistics 2007). With respect to homework, in a typical spring school week in the NLYS97, 10 percent of enrolled students aged 12-14 did not spend any time doing homework (authors' own calculation). Our numbers for the ATUS are not directly comparable because our students are older than those in the NLSY97 and because we measure activity on a single day rather than over the course of a week. However, the NLSY97 shows that, even over the course of a week, there is still a substantial degree of nonparticipation.

\footnotetext{
${ }^{6}$ See www.dol.gov/whd/state/nonfarm.htm\#footc for a chart describing some of the federal and state restrictions on student employment.
} 
Table 2 reports by work status the average minutes spent in different activities on school days. The first column presents the average time spent on schooldays, regardless of employment status. The second and third columns divide the sample by whether or not the student was employed during the previous week, and the last two columns divide the sample by whether or not the student worked on the diary day. The "employed during the previous week" variable is a measure of whether a high school student has a job. Results using this variable are intended to capture the effects of having a job on a student's daily activities. Because some of the students who are classified by this variable as employed may not be working on the diary day, any effects found for this variable are averages across work and non-work days for employed students. The "worked on the diary day" variable is a better measure of the effect of how a student's working on a particular day constrains the amount of time remaining for other activities on that day. Depending on the research question to be asked, one might prefer to use one variable over the other. Those interested in the implications of encouraging student employment in general may be interested in the "employed during the previous week" variable. Those interested in the effects of working on school days versus non-school days may be more interested in the "worked on the diary day” variable. However, using either definition, working students spend less time, on average, than non-working students on homework, sleep, and screen time on school days. This is also true when the homework category is expanded to include other extra-curricular activities and sports and the screen time category is expanded to include games.

Table 3 shows average minutes spent in different activities on non-school days for the full sample and for subsamples defined by work status. In general, the amount of homework that is being done by students is, not surprisingly, lower on non-school days than on school days. Students also sleep more and engage in more screen time on non-school days than school days. 
Differences across work statuses for school days also appear to hold up for non-school days. The exception is the basic homework category, where no statistically significant differences across work statuses are found.

In our multivariate analyses, we include measures of students' demographic and household characteristics, as well as a measure of labor market conditions. For several reasons, we include an indicator variable for whether or not a parent has a bachelor's degree. First, we include it because parents' education levels may capture preferences toward education that are passed on to their children and thus affect the time a student chooses to spend doing homework. Second, it is also strongly correlated with parental income and thus may affect whether a student works to earn spending money. Third, Porterfield and Winkler (2007) suggest that parents' education levels may affect their child's access to jobs. Fourth, parental education may affect how much TV and computer time a student is allowed. Parents are currently encouraged by the American Academy of Pediatrics (2007) to limit the time their children devote to watching TV and playing video games to no more than two hours per day. One might expect more educated parents to be more informed about and pay more attention to this advice.

Another parental variable that we include is an indicator for whether a teen lives in a single-parent household. This variable is probably negatively correlated with the degree of parental supervision and thus may affect the time teenagers spend on homework or sleep (Kalenkoski et al. 2009, Wight et al. 2009). We also include a variable for the number of siblings under age 15 . We expect that this variable will affect homework time because, the greater the number of siblings, especially younger siblings who are more likely to need their parents' help with homework, the less time a parent has available to help with the teen's homework and perhaps the less parental supervision of his/her homework that occurs. In 
addition, younger siblings may limit the teen's ability to work outside the home if they cause a parent to be unable to transport the teen to work or if the parent requires the teen to babysit his/her siblings. However, having a greater number of younger siblings may increase the likelihood that a teen works if the larger family size leads to a decreased share of family resources for the teen. It is also likely that a teen may spend more time watching TV or using a computer to communicate with friends if there are no siblings to play with in the home.

Other explanatory variables created from the ATUS include an indicator variable for whether or not the teen respondent is female; indicators for ages 16, 17, and 18 (with age 15 being the omitted category because 15-year-olds are quite limited in the work they are legally able to do); indicators for being black and Hispanic; and an indicator for SMSA status.

Finally, we also include the state monthly unemployment rate from the U.S. Bureau of Labor Statistics' Local Area Unemployment Statistics (LAUS) program. This is matched to the ATUS data using the state identifier. As a measure of labor market conditions, the unemployment rate is likely to affect whether a student has a job. See the appendix, Table A2, for means and standard deviations for the control variables used in our analyses.

\section{Econometric Model}

Because screen time (C) and time spent on homework (H) are recorded as zero for a substantial number of respondents, we model time spent in each of these activities as a censored regression (Tobit). ${ }^{7}$ Sleep (S) is modeled as a non-censored regression because all students

\footnotetext{
${ }^{7}$ To the extent that these zero values represent no participation in these activities, a non-censored regression model would give biased results. However, if students are truly participants but we interview them on an "off” day when they do not participate, then a non-censored regression
} 
report some sleep. In addition, whether or not a student engages in paid work (E) is potentially endogenously chosen with the time s/he spends in other activities. Therefore, we estimate the following mixed-process model that includes a Tobit for homework time, a Tobit for screen time, a non-censored regression for sleep time, and a probit for employment:

$$
\begin{aligned}
& \mathrm{H}_{\mathrm{i}}^{*}=\gamma_{\mathrm{h}} \mathrm{E}_{\mathrm{i}}+\beta_{\mathrm{h}} \mathrm{X}_{\mathrm{i}}+\mathrm{h}_{\mathrm{i}} \\
& \mathrm{H}_{\mathrm{i}}=\mathrm{H}_{\mathrm{i}}^{*} \text { if } \mathrm{H}_{\mathrm{i}}^{*}>0 \\
& \mathrm{H}_{\mathrm{i}}=0 \text { if } \mathrm{H}_{\mathrm{i}}^{*} \leq 0 \\
& \mathrm{C}_{\mathrm{i}}^{*}=\gamma_{\mathrm{c}} \mathrm{E}_{\mathrm{i}}+\beta_{\mathrm{c}} \mathrm{X}_{\mathrm{i}}+\mathrm{C}_{\mathrm{i}} \\
& \mathrm{C}_{\mathrm{i}}=\mathrm{C}_{\mathrm{i}}^{*} \text { if } \mathrm{C}_{\mathrm{i}}^{*}>0 \\
& \mathrm{C}_{\mathrm{i}}=0 \text { if } \mathrm{C}_{\mathrm{i}}^{*} \leq 0 \\
& \mathrm{~S}=\gamma_{\mathrm{s}} \mathrm{E}_{\mathrm{i}}+\beta_{\mathrm{s}} \mathrm{X}_{\mathrm{i}}+\mathrm{S}_{\mathrm{i}} \\
& \mathrm{E}_{\mathrm{i}}^{*}=\alpha \mathrm{Z}_{\mathrm{i}}+\mathrm{e}_{\mathrm{i}} \\
& \mathrm{E}_{\mathrm{i}}=1 \text { if } \mathrm{E}_{\mathrm{i}}^{*}>0 \\
& \mathrm{E}_{\mathrm{i}}=0 \text { if } \mathrm{E}_{\mathrm{i}}^{*} \leq 0
\end{aligned}
$$

$\mathrm{H}_{\mathrm{i}}^{*}, \mathrm{C}_{\mathrm{i}}^{*}$, and $\mathrm{E}_{\mathrm{i}}^{*}$ are the latent variables behind the observed variables $\mathrm{H}_{\mathrm{i}}, \mathrm{C}_{\mathrm{i}}$, and $\mathrm{E}_{\mathrm{i}}$, where $\mathrm{i}$ refers to the individual respondent. $\mathrm{X}_{\mathrm{i}}$ is the vector of the respondent's personal and household characteristics. $Z_{\mathrm{i}}$ is equal to $\mathrm{X}_{\mathrm{i}}$ plus one additional variable to help identify employment status

model would provide consistent estimates. Our assumption is that, while we may catch some students on "off" days where they do not participate, there is true non-participation in homework and screen time that must be accounted for by using Tobits. 
in the other equations. ${ }^{8} \beta_{\mathrm{h}}, \beta_{\mathrm{c}}$, and $\beta_{\mathrm{s}}$ are the vectors of coefficients on $\mathrm{X}_{\mathrm{i}}$ in the latent homework, latent screen time, and observed sleep equations, respectively, and $\alpha$ is the vector of coefficients on $\mathrm{Z}_{\mathrm{i}}$ in the employment equation. The key coefficients of interest are $\gamma_{\mathrm{h}}, \gamma_{\mathrm{c}}$, and $\gamma_{\mathrm{s}}$, the effects of employment on latent homework, latent screen time, and observed sleep time, respectively. $h_{i}, c_{i}, s_{i}$, and $e_{i}$ are the error terms in each of these equations and follow a multivariate normal distribution. ${ }^{9}$ One can think of the homework, sleep, and screen time equations as "structural” equations and the employment equation as a "reduced form” equation. Therefore, the model is estimated via Limited Information Maximum Likelihood using the “cmp” command in STATA (Roodman 2009). ${ }^{10}$

\section{Results}

Recall that we measure employment, $\mathrm{E}_{\mathrm{i}}$, in two different ways, first as working at any point during the previous week, and second, as working on the diary day. Therefore, we provide separate estimates for each of these alternative measures. The explanatory variables in $\mathrm{X}_{\mathrm{i}}$ include the exogenous regressors identifying students’ personal and household characteristics, as

\footnotetext{
${ }^{8}$ Note, however, that because of non-linearities in this model, this additional variable is not necessary for identification, although identification might be more robust if exclusion restrictions are imposed (Roodman 2009, p. 27-28).

${ }^{9}$ Single-equation estimates that do not allow for correlated errors or control for the endogeneity of employment are available from the authors upon request.

${ }^{10}$ The “cmp” command was created by David Roodman (2009) to estimate recursive but not fully-simultaneous mixed-process models.
} 
described in the data section. ${ }^{11}$ The additional variable in $\mathrm{Z}_{\mathrm{i}}$ that is not in $\mathrm{X}_{\mathrm{i}}$ is the state unemployment rate. The state unemployment rate identifies the employment variable in the other equations, although, as noted earlier, it is not required. ${ }^{12}$

In Table 4, for school days, we report coefficients, standard errors, and marginal effects for our "employed during the previous week" variable. Being employed reduces a student's daily homework time on a school day by 45 minutes, a rather substantial amount given that the average daily minutes spent on homework using the entire sample of students is just 49 minutes. Perhaps surprisingly, employed students sleep 148 minutes more than non-employed students on school days. This could be due to fatigue, resulting from a combination of in-class time and work time on such days. The results also indicate that screen time is lower for employed students by 20 minutes, but this result is not statistically significant.

Results for the other coefficients are generally as expected. The probability of employment decreases the higher the unemployment rate and increases the greater the student's age. Having a parent with a bachelor's degree reduces the probability of employment. Being black or Hispanic also reduces the probability of employment. An increase in the number of younger siblings, however, raises the probability of employment. Females do more homework,

${ }^{11}$ In one school-day specification (not reported here), we also included an indicator for Fridays because students may behave differently when they do not have to go to school the following day. Results were similar in magnitude. However, we do not include this specification throughout because some of our sensitivity analyses would not converge with this additional variable.

${ }^{12}$ Unemployment rates have been used by other researchers to identify hours worked by students (e.g., Rothstein 2007; Kalenkoski and Pabilonia 2009b). 
sleep less, and engage in less screen time than male students. Older students sleep less than younger students, while black and Hispanic students sleep more than other students. Importantly, several of the estimated correlations among the error terms of the different equations are highly statistically significant, supporting our joint estimation of these equations. For example, the correlation between the unobserved determinants of employment and homework is statistically significant and positive, suggesting that an unobserved variable, such as student motivation, affects both employment and homework in the same way. Similarly, the negative correlations between the unobserved determinants of employment and sleep, homework and sleep, and homework and screen time may reflect a strong but unmeasured relative preference for work over leisure.

Table 5 shows the effects of being employed last week on time use on non-school days. Students who are employed spend 32 fewer minutes on homework on non-school days than students who are not employed, a smaller effect than on school days, as expected. The reduction in screen time, however, is quite large at 168 minutes (more than $2 \frac{1}{2}$ hours), and is also statistically significant, unlike on school days. The magnitude of the effect of employment on sleep on non-school days is about the same as that for non-school days, but the sign is in the opposite direction. On non-school days, employed students sleep $2 \frac{1}{2} 2$ hours less than nonemployed students. Many of the estimated effects of the other variables on the different uses of time on non-school days are similar to those on school days. Similar to the results for school days, most of the error correlation coefficients are statistically significant, again supporting joint estimation of these equations.

Table 6 shows the effects of working on the diary day when the diary day is a school day. The estimated effects of working on the diary day are of the same signs, but are slightly larger in 
magnitude than, the effects of being employed in the previous week. This is to be expected, as the effect of being employed the previous week averages the effects for students who are working with those who are not working on the diary day. Students who worked on the diary day spent 50 fewer minutes on homework than did students who did not work. Students who worked slept 165 minutes more than those who did not work. Screen time is lower by 32 minutes for students who worked but, as with the results for "employed in the previous week," this estimate is statistically insignificant. Similar to the results for the other employment measure, the estimated correlation coefficients on the errors are almost all statistically significant.

Table 7 shows the effects of working on the diary day for non-school days. Again, these results are similar in sign but generally of greater magnitude than those using the worked last week measure of employment. ${ }^{13}$ Students who worked spent 43 fewer minutes on homework, slept 204 fewer minutes (almost 3 1/2 hours), and engaged in 163 fewer minutes of screen time than those who did not. Similar to the results for the other employment measure, the estimated correlation coefficients on the errors are almost all statistically significant.

\section{Sensitivity Analyses}

The results that we have just presented were based on a sample that included 15- to 18year-old students. However, 15-year-olds face many more legal restrictions on the types of jobs they may hold and the hours they are allowed to work than 16- to 18-year-olds (Pabilonia

\footnotetext{
13 The exception is screen time, where the effect of working on the diary day is slightly smaller than that for the employed the previous week measure.
} 
2001). ${ }^{14}$ While the age dummies used in the previous models do control somewhat for student age, they donot allow employment effects to differ for 15 and 16- to 18-year-olds. Therefore, we re-estimate all of the models using the smaller 16- to 18 -year-old sample. ${ }^{15}$ Table 8 presents the estimated effects of being employed the previous week and working on the diary day on homework, sleep, and screen time. The results are very similar to those from the larger sample, although some of the effects are slightly larger.

We also estimated several specifications using alternative time use categories. The key results are shown in Table 9. First, we expanded the homework category to include non-sport extracurricular activities. Next, we included both non-sport extracurricular activities and sports. Third, we report results for the effect of employment on night sleep, as opposed to total diary day sleep. Finally, we expanded the screen time category to include games. The results for all three of the broader homework and screen time categories are similar to those for the narrower categories. Adding additional activities, however, does increase the estimated effects of being employed the previous week and working on the diary day. This suggests that the additional activities that we have included in these sensitivity analyses are affected in ways similar to the original set of activities. The results for nighttime sleep on school days, however, are different from our previous results in Tables 4 and 6 for diary day sleep. We find that working on a school-day diary day leads to less, rather than more, subsequent nighttime sleep. However, our

\footnotetext{
${ }^{14}$ See also www.dol.gov/whd/state/nonfarm.htm\#footc.

${ }^{15}$ Eighteen-year-olds face fewer restrictions than 16- and 17-year olds, but the samples of 18year-olds only and 16- and 17-year olds are too small to obtain separate estimates.
} 
results for non-school days are of the same sign regardless of whether we consider diary-day or nighttime sleep. ${ }^{16}$

Finally, in an attempt to distinguish the effects of simply having a job from actually working on the diary day, we estimated a model that included both an indicator variable for being employed in the previous week and an interaction of this variable with an indicator variable for working on the diary day. Thus, in this model, the base/comparison category was not employed. Unfortunately, the model did not converge separately for school days and nonschool days, so we instead estimated it over the combined sample of school days and non-school days (Table 10). This enabled us to include an additional variable in the employment probit, the state unemployment rate interacted with the school day dummy, to help identify the additional endogenous variable in this model. According to this combined model, neither having a job nor working on the diary day has a statistically significant effect on homework, a result that differs from our other analyses. Having a job by itself also does not affect sleep time, but working on the diary day reduces sleep time, as we found in our non-school day and nighttime sleep models. Both having a job and working on the diary day do reduce screen time, as in our other models, and the combined statistically significant effect of having a job and working on the diary day is a reduction in screen time of 140 minutes. Thus, these results are not that different from our main results. However, because this model asks a lot of the data, and because we cannot break down the effects by whether or not the diary day is a school day, these particular results should be interpreted with caution.

\footnotetext{
${ }^{16}$ The nighttime sleep effects are smaller in magnitude than the total diary day effects, however, because nighttime sleep does not include daytime naps.
} 


\section{Discussion and Conclusions}

Using time-diary data from the ATUS, this paper examines the effects of high school students' employment on the time that they spend in their other major activities. Our results suggest that employment decreases the time high school students spend on human-capitalbuilding activities, such as homework and extracurricular activities, but also decreases screen time, which may be considered unproductive time. They also suggest that employment increases sleep on school days but decreases it on non-school days. These school-day results were unexpected, given the popular notion that working causes students to sleep less. These results are robust to the employment measure used, so perhaps the positive effect of working on school days is caused by student fatigue due to a heavy schedule of in-class time and work on such days. However, it is useful to note that our sensitivity analysis that investigates nighttime sleep on school days does have the expected negative sign. More research on the timing of sleep and how it is measured in time diaries may help explain these results. Perhaps students plan for their late work nights by sleeping in or taking naps prior to working on school days.

Predictions for sleep and screen time based on the estimated models can be compared to recommendations from the National Sleep Foundation and the American Academy of Pediatrics. In Table 11, we show the average predictions for different groups based on employment status (either measure) and whether or not the diary day was a school day. The National Sleep Foundation recommends that teenagers get 8.5-9.25 hours of sleep per night. On school days, employed students and students working on the diary day sleep more than the recommended amount, on average. However, other students sleep less than the recommended amount. On non-school days, only those students who worked on those days sleep less than the 
recommended amount. One possible explanation for the differences across type of day may be that regulations that limit work on school days leave ample time for sleep while more lax regulations regarding student work hours on non-school days do not.

With respect to screen time, the American Academy of Pediatrics recommends no more than two hours of TV and video games per day. Despite all of the concern in the popular press that teens are spending too much time on these activities, the average time spent on these activities on school days is around the recommended two hour limit. However, on non-school days, those students who are not employed and those that are not working on those days spend much more than the recommended time on these activities, suggesting that student employment may have the beneficial effect of reducing time spent on these unproductive activities.

In general, our results suggest mixed effects of employment on students' activities. It has a negative effect on human-capital-building activities, such as homework and extra-curricular activities. However, it has the beneficial effect of reducing unproductive screen time and, at least on school days, the beneficial effect of students meeting the recommended sleep guidelines. 


\section{References}

Aksoy, T. and C.R. Link. (2000). "A Panel Analysis of Student Math Achievement in the US in the 1990s: Does Increasing the Amount of Time in Learning Activities Affect Math Achievement?” Economics of Education Review 19; 261-277.

American Academy of Pediatrics. (2007). "Television and the Family.” http://www.aap.org/publiced/BR_TV.htm

Barron, J.M., B.T. Ewing, and G.R. Waddell. (2000). “The Effects of High School Athletic Participation on Education and Labor Market Outcomes.” Review of Economics and Statistics 82(3); 409-421.

Betts, J. (1997). “The Role of Homework in Improving School Quality.” Unpublished manuscript.

Bianchi, S.M., Robinson, J.P., and Milkie, M.A. (2006). Changing Rhythms of American Family Life. New York: Russell Sage.

Brint, Steven, and Allison M. Cantwell. (2008). “Undergraduate Time Use and Academic Outcomes: Results from UCUES 2006.” Working paper.

Bureau of Labor Statistics. (2005). Work Activity of High School Students: Data from the National Longitudinal Survey of Youth 1997. http://www.bls.gov/nls/nlsy97r6.pdf Bureau of Labor Statistics. (2007). College Enrollment and Work Activity of 2006 High School Graduates. http://www.bls.gov/news.release/hsgec.nr0.htm

Dustmann C. and A. Van Soest. (2007). "Part-time Work, School Success and School Leaving,” Empirical Economics 32(2-3); 277-299.

Eren, O. and D.J. Henderson. (2007) "The Impact of Homework on Student Achievement," Econometrics Journal 11; 326-348. 
Hotz, V.J., Xu, L.C., Tienda, M., and A. Ahituv. (2002). “Are there Returns to the Wages of Young Men from Working While in School?” Review of Economics and Statistics 84(2); 221-236.

Juster, F.T. (1985). “The Validity and Quality of Time Use Estimates Obtained from Recall Diaries.” In: F. Thomas Juster and Frank P. Stafford (eds.) Time, Goods, and Well-Being. Survey Research Center, Institute for Social Research, University of Michigan: Ann Arbor, Michigan; 63-91.

Kalenkoski, C.M. and S.W. Pabilonia. (2009a). “Does Working While in High School Reduce U.S. Study Time?” Social Indicators Research 93(1); 117-121.

Kalenkoski, C.M. and S.W. Pabilonia. (2009b). “Parental Transfers, Student Achievement, and the Labor Supply of College Students,” Forthcoming in Journal of Population Economics.

Kalenkoski, C.M., D.C. Ribar, and L.S. Stratton (2009). “How Do Adolescents Spell Time Use?” IZA Discussion Paper No. 4374.

Kuhn, P. and C. Weinberger. (2005). “Leadership Skills and Wages”. Journal of Labor Economics 23(3); 395-436.

Light, A. (1999). “High School Employment, High School Curriculum, and Post-School Wages,” Economics of Education Review 18(3); 291-309.

Light, A. (2001). “In-School Work Experience and the Returns to Schooling,” Journal of Labor Economics 19(1); 65-93.

Lipscomb, S. L. (2007). 'Secondary School Extracurricular Involvement and Academic Achievement: A Fixed Effects Approach.” Economics of Education Review 26 (4); 463472. 
Michael, R.T. and N.B. Tuma (1984). “Youth Employment: Does Life Begin at 16?” Journal of Labor Economics 2(4); 464-476.

Neumark, D. and M. Joyce (2001). “Evaluating School-to-Work Programs Using the New NLSY,” Journal of Human Resources 36(4); 666-702.

Oettinger, G.S. (1999). “Does High School Employment Affect High School Academic Performance?” Industrial and Labor Relations Review 53(1); 136-151.

Pabilonia, S.W. (2001). “Evidence on Youth Employment, Earnings, and Parental Transfers in the National Longitudinal Survey of Youth 1997.” Journal of Human Resources 36(4); 795-822.

Persico, N., A. Postlewaite, and D. Silverman. (2004). “The Effect of Adolescent Experience on Labor Market Outcomes: The Case of Height.” Journal of Political Economy 112(5); 1019-1053.

Peszka, J.J., Mastin D.F., and J.R. Harsh. (2009). “Chronotype, Sleep Hygiene, and Academic Performance in High School and College.” Presented at the Associated Professional Sleep Societies in Seattle, WA 2009.

Porterfield, S.L. and A.E. Winkler. (2007). “Teen Time Use and Parental Education: Evidence from the CPS, MTF, and ATUS.” Monthly Labor Review 130(5); 37-56.

Rothstein, D.S. (2007). “High School Employment and Youths’ Academic Achievement,” Journal of Human Resources 42(1); 194-213.

Roodman, David. (2009). “Estimating Fully Observed Recursive Mixed-Process Models with cmp.” CGD Working Paper 168. Washington, D.C.: Center for Global Development. http://www.cgdev.org/content/publications/detail/1421516/ 
Ruhm, C.J. (1995). “The Extent and Consequences of High School Employment,” Journal of Labor Research 16(3); 293-304.

Ruhm, C.J. (1997). “Is High School Employment Consumption or Investment?” Journal of Labor Economics 15(4); 735-776.

Stephenson, S.P. (1981). “In-School Labour Force Status and Post-School Wage Rates of Young Men,” Applied Economics 13(3); 279-302.

Stinebrickner R. and T.R. Stinebrickner. (2004). “Time Use and College Outcomes.” Journal of Econometrics 121(1-2); 243-269.

Stinebrickner R. and T.R. Stinebrickner. (2008). "The Causal Effect of Studying on Academic Performance.” The B.E. Journal of Economic Analysis and Policy (Frontiers) 8(1), Article 14; 1-53.

Tyler, J.H. (2003). “Using State Child Labor Laws to Identify the Effect of School-Year Work on High School Achievement,” Journal of Labor Economics 21(2); 353-380.

Warren, J.R., P. LePore, and R. Mare (2001). “Employment during High School: Consequences for Students’ Grades in Academic Courses,” Journal of Vocational Education Research 26(3); 943-969.

Wight, V., J. Price, S. Bianchi , and B. Hunt. (2009). “The Time Use of Teenagers,” Social Science Research 38(4); 792-809. 
Table 1. Percentage Not Participating in a Given Activity

\begin{tabular}{lc|cc}
\hline Time Use Variables & Total & School days & $\begin{array}{c}\text { Non-school } \\
\text { days }\end{array}$ \\
\hline Employed during previous week & 67 & 67 & 67 \\
Paid work on diary day & 86 & 86 & 86 \\
Homework on diary day & 56 & $\mathbf{4 9}$ & $\mathbf{7 1}$ \\
Homework/Extracurricular on diary day & 53 & $\mathbf{4 6}$ & $\mathbf{6 9}$ \\
Homework/Extracurricular/Sports on diary day & 37 & $\mathbf{3 2}$ & $\mathbf{4 8}$ \\
Sleep on diary day & 0 & 0 & 0 \\
Night sleep & 0 & 0 & 0 \\
Screen time on diary day & 20 & $\mathbf{2 2}$ & $\mathbf{1 7}$ \\
Screen/Games on diary day & 16 & $\mathbf{1 8}$ & $\mathbf{1 2}$ \\
Number of observations & 3,027 & 1,410 & 1,607 \\
\hline
\end{tabular}

Note: Weighted percentages used. Means stated in bold are significantly different at the $5 \%$ level. 
Table 2. Average Minutes per Day Spent in Each Activity on School Days, By Employment in Previous Week and Working Status on Diary Day

\begin{tabular}{lc|cc|cc}
\hline & Total & $\begin{array}{c}\text { Employed } \\
\text { Previous } \\
\text { Week }\end{array}$ & $\begin{array}{c}\text { Not Employed } \\
\text { Previous } \\
\text { Week }\end{array}$ & $\begin{array}{c}\text { Worked on Diary } \\
\text { Day }\end{array}$ & $\begin{array}{c}\text { Did Not Work } \\
\text { on Diary Day }\end{array}$ \\
\hline Paid Work & 32.33 & 97.20 & & 235.07 & \\
Homework & 52.24 & $\mathbf{4 2 . 2 0}$ & $\mathbf{5 7 . 2 5}$ & $\mathbf{2 9 . 2 1}$ & $\mathbf{5 5 . 9 2}$ \\
Homework / Extracurricular & 60.21 & $\mathbf{4 9 . 9 4}$ & $\mathbf{6 5 . 3 2}$ & $\mathbf{3 6 . 4 1}$ & $\mathbf{6 4 . 0 0}$ \\
Homework/Extracurricular/Sports & 100.46 & $\mathbf{7 7 . 4 4}$ & $\mathbf{1 1 1 . 9 3}$ & $\mathbf{5 0 . 3 0}$ & $\mathbf{1 0 8 . 4 6}$ \\
Sleep on diary day & 514.51 & $\mathbf{4 9 7 . 1 1}$ & $\mathbf{5 2 3 . 1 8}$ & $\mathbf{4 8 6 . 5 8}$ & $\mathbf{5 1 8 . 9 6}$ \\
Night sleep & 491.25 & $\mathbf{4 9 3 . 2 2}$ & $\mathbf{5 1 0 . 5 2}$ & $\mathbf{4 9 3 . 2 2}$ & $\mathbf{5 1 0 . 5 2}$ \\
Screen Time & 121.60 & $\mathbf{1 0 5 . 5 7}$ & $\mathbf{1 2 9 . 5 9}$ & $\mathbf{7 5 . 1 4}$ & $\mathbf{1 2 9 . 0 1}$ \\
Screen/Games & 143.79 & $\mathbf{1 2 0 . 2 1}$ & $\mathbf{1 5 5 . 5 5}$ & $\mathbf{8 6 . 5 6}$ & $\mathbf{1 5 2 . 9 2}$ \\
Number of observations & 1,410 & 479 & 941 & 193 & 1,227 \\
\hline
\end{tabular}

Note: Averages are weighted. Means stated in bold are significantly different at the $5 \%$ level. 
Table 3. Average Minutes per Day Spent in Each Activity on Non-School Days, By Employment in Previous Week and Working Status on Diary Day

\begin{tabular}{lc|cc|cc}
\hline & & $\begin{array}{c}\text { Not } \\
\text { Employed } \\
\text { Previous } \\
\text { Week }\end{array}$ & $\begin{array}{c}\text { Employed } \\
\text { Previous } \\
\text { Week }\end{array}$ & $\begin{array}{c}\text { Worked on } \\
\text { Diary Day }\end{array}$ & $\begin{array}{c}\text { Did Not Work } \\
\text { on Diary Day }\end{array}$ \\
\hline Paid Work & 48.74 & 149.56 & & 353.85 & \\
Homework & 40.79 & 39.70 & 41.32 & 32.81 & 42.07 \\
Homework / Extracurricular & 46.79 & 46.41 & 46.97 & $\mathbf{3 5 . 8 7}$ & $\mathbf{4 8 . 5 4}$ \\
Homework/Extracurricular/Sports & 92.97 & 87.86 & 98.62 & $\mathbf{5 5 . 7 4}$ & $\mathbf{9 8 . 9 1}$ \\
Sleep on diary day & 629.93 & $\mathbf{5 9 8 . 0 9}$ & $\mathbf{6 4 5 . 3 3}$ & $\mathbf{5 7 5 . 6 6}$ & $\mathbf{6 3 8 . 6 0}$ \\
Night sleep & 502.77 & $\mathbf{5 0 9 . 0 7}$ & $\mathbf{5 3 6 . 0 2}$ & $\mathbf{5 0 9 . 0 6}$ & $\mathbf{5 3 6 . 0 1}$ \\
Screen Time & 177.67 & $\mathbf{1 3 9 . 1 9}$ & $\mathbf{1 9 6 . 2 7}$ & $\mathbf{1 0 6 . 3 8}$ & $\mathbf{1 8 9 . 0 6}$ \\
Screen/Games & 219.80 & $\mathbf{1 6 7 . 6 7}$ & $\mathbf{2 4 5 . 0 0}$ & $\mathbf{1 2 3 . 1 5}$ & $\mathbf{2 3 5 . 2 3}$ \\
Number of observations & 1,607 & 552 & 1,055 & 233 & 1,228 \\
\hline Not: Averat
\end{tabular}

Note: Averages are weighted. Means stated in bold are significantly different at the $5 \%$ level. 
Table 4. Effects of Employment during Previous Week on Time Use on a School Day:

Models Estimated Jointly

\begin{tabular}{|c|c|c|c|c|}
\hline & (1) & (2) & (3) & (4) \\
\hline VARIABLES & Probit Employed & Tobit Homework & Non-censored Sleep & $\begin{array}{l}\text { Tobit } \\
\text { Screen }\end{array}$ \\
\hline Employed previous week & & $\begin{array}{l}-96.05^{* * *} \\
(31.47) \\
{[-44.64]}\end{array}$ & $\begin{array}{l}147.88^{* * *} \\
(18.51)\end{array}$ & $\begin{array}{c}-27.13 \\
(44.64) \\
{[-20.17]}\end{array}$ \\
\hline State unemployment rate & $\begin{array}{c}-0.05^{*} \\
(0.03) \\
{[-0.02]}\end{array}$ & & & \\
\hline Female & $\begin{array}{c}0.03 \\
(0.07) \\
{[0.01]}\end{array}$ & $\begin{array}{c}32.08^{* * *} \\
(7.35) \\
{[16.48]}\end{array}$ & $\begin{array}{c}-12.35^{*} \\
(7.90)\end{array}$ & $\begin{array}{c}-23.44 * * * \\
(8.06) \\
{[-17.63]}\end{array}$ \\
\hline Age 16 & $\begin{array}{l}0.53 * * * \\
(0.10) \\
{[0.17]}\end{array}$ & $\begin{array}{r}11.14 \\
(11.18) \\
{[5.70]}\end{array}$ & $\begin{array}{l}-35.66^{* * *} \\
(10.86)\end{array}$ & $\begin{array}{r}6.03 \\
(13.23) \\
{[4.60]}\end{array}$ \\
\hline Age 17 & $\begin{array}{l}0.77 * * * \\
(0.10) \\
{[0.25]}\end{array}$ & $\begin{array}{r}12.52 \\
(13.25) \\
{[6.44]}\end{array}$ & $\begin{array}{l}-52.39 * * * \\
(11.68)\end{array}$ & $\begin{array}{c}-3.77 \\
(16.21) \\
{[-2.84]}\end{array}$ \\
\hline Age 18 & $\begin{array}{l}0.90 * * * \\
(0.13) \\
{[0.30]}\end{array}$ & $\begin{array}{c}-17.17 \\
(17.74) \\
{[-8.09]}\end{array}$ & $\begin{array}{l}-58.49 * * * \\
(15.94)\end{array}$ & $\begin{array}{c}-28.75 \\
(21.00) \\
{[-20.86]}\end{array}$ \\
\hline Parent has bachelor's degree & $\begin{array}{l}-0.16^{* *} \\
(0.08) \\
{[-0.05]}\end{array}$ & $\begin{array}{c}34.24^{* * *} \\
(8.25) \\
{[17.97]}\end{array}$ & $\begin{array}{l}-2.87 \\
(8.79)\end{array}$ & $\begin{array}{c}-6.81 \\
(9.38) \\
{[-5.11]}\end{array}$ \\
\hline Single-parent household & $\begin{array}{c}-0.06 \\
(0.08) \\
{[-0.02]}\end{array}$ & $\begin{array}{c}-22.41 * * * \\
(8.67) \\
{[-11.19]}\end{array}$ & $\begin{array}{l}10.86 \\
(9.19)\end{array}$ & $\begin{array}{c}3.31 \\
(9.38) \\
{[2.50]}\end{array}$ \\
\hline Black & $\begin{array}{l}-0.42^{* * *} \\
(0.13) \\
{[-0.14]}\end{array}$ & $\begin{array}{c}-26.59 * * \\
(14.16) \\
{[-12.98]}\end{array}$ & $\begin{array}{l}43.17^{* * *} \\
(14.14)\end{array}$ & $\begin{array}{c}25.81^{*} \\
(15.62) \\
{[19.87]}\end{array}$ \\
\hline Hispanic & $\begin{array}{l}-0.49 * * * \\
(0.11) \\
{[-0.16]}\end{array}$ & $\begin{array}{c}-12.99 \\
(12.43) \\
{[-6.59]}\end{array}$ & $\begin{array}{l}42.26^{* * * *} \\
(12.36)\end{array}$ & $\begin{array}{r}10.64 \\
(14.33) \\
{[8.03]}\end{array}$ \\
\hline Siblings under age 15 & $\begin{array}{c}0.06^{*} \\
(0.04) \\
{[0.02]}\end{array}$ & $\begin{array}{c}-6.22 \\
(4.09) \\
{[-3.22]}\end{array}$ & $\begin{array}{c}0.13 \\
(4.34)\end{array}$ & $\begin{array}{c}-15.74 * * * \\
(4.51) \\
{[-11.98]}\end{array}$ \\
\hline Sigma & & $\begin{array}{l}125.26^{* * *} \\
(5.42)\end{array}$ & $\begin{array}{l}148.52 * * * \\
(5.17)\end{array}$ & $\begin{array}{c}147.46^{* * * *} \\
(3.25)\end{array}$ \\
\hline Rho_Employed_Homework & $\begin{array}{l}0.34 * * * \\
(0.14)\end{array}$ & & & \\
\hline Rho_Employed_Sleep & $\begin{array}{l}-0.70 * * * \\
(0.05)\end{array}$ & & & \\
\hline Rho_Employed_Screen & $\begin{array}{l}-0.01 \\
(0.18)\end{array}$ & & & \\
\hline Rho_Homework_Sleep & $\begin{array}{l}-0.24 * * * \\
(0.06)\end{array}$ & & & \\
\hline Rho_Homework_Screen & $\begin{array}{l}-0.26^{* * * *} \\
(0.05)\end{array}$ & & & \\
\hline Rho_Sleep_Screen & $\begin{array}{c}0.05 \\
(0.08)\end{array}$ & & & \\
\hline $\begin{array}{l}\text { Log-likelihood } \\
\text { Observations }\end{array}$ & $\begin{array}{c}-22,105.43 \\
1,420\end{array}$ & 1,420 & 1,420 & 1,420 \\
\hline
\end{tabular}

Standard errors are in parentheses. Marginal effects are in brackets. Reported marginal effects are averages of individual marginal effects rather than effects calculated at the average of the explanatory variables. They are for discrete changes in the indicator variable. For the Tobit model, marginal effects are calculated for the unconditional expected value. Regressions also include region, season, and whether the respondent resides in an SMSA. Significance levels: $* * * \mathrm{p}<0.01,{ }^{* *} \mathrm{p}<0.05,{ }^{*} \mathrm{p}<0.1$. 
Table 5. Effects of Employment during Previous Week on Time Use on a Non-School Day: Models Estimated Jointly

\begin{tabular}{|c|c|c|c|c|}
\hline & (1) & $(2)$ & (3) & (4) \\
\hline Variables & Probit Employed & Tobit Homework & Non-censored Sleep & Tobit Screen \\
\hline Employed previous week & & $\begin{array}{c}-114.96 * \\
(58.80) \\
{[-32.42]}\end{array}$ & $\begin{array}{c}-152.21 * * * \\
(30.49)\end{array}$ & $\begin{array}{c}-229.67 * * * \\
(36.06) \\
{[-167.66]}\end{array}$ \\
\hline State unemployment rate & $\begin{array}{c}-0.09 * * * \\
(0.03) \\
{[-0.03]}\end{array}$ & & & \\
\hline Female & $\begin{array}{c}-0.06 \\
(0.06) \\
{[-0.02]}\end{array}$ & $\begin{array}{c}81.56 * * * \\
(13.66) \\
{[25.24]}\end{array}$ & $\begin{array}{l}-6.69 \\
(7.63)\end{array}$ & $\begin{array}{c}-34.47 * * * \\
(9.79) \\
{[-26.53]}\end{array}$ \\
\hline Age 16 & $\begin{array}{c}0.38 * * * \\
(0.09) \\
{[0.11]}\end{array}$ & $\begin{array}{c}38.29 * * \\
(19.59) \\
{[10.83]}\end{array}$ & $\begin{array}{c}7.72 \\
(10.63)\end{array}$ & $\begin{array}{c}-2.97 \\
(13.52) \\
{[-2.26]}\end{array}$ \\
\hline Age 17 & $\begin{array}{c}0.86 * * * \\
(0.09) \\
{[0.28]}\end{array}$ & $\begin{array}{c}66.67 * * * \\
(26.09) \\
{[20.25]}\end{array}$ & $\begin{array}{c}15.00 \\
(13.50)\end{array}$ & $\begin{array}{c}24.25 \\
(16.83) \\
{[18.60]}\end{array}$ \\
\hline Age 18 & $\begin{array}{c}0.97 * * * \\
(0.12) \\
{[0.33]}\end{array}$ & $\begin{array}{c}36.82 \\
(33.81) \\
{[10.37]}\end{array}$ & $\begin{array}{c}26.94 \\
(17.57)\end{array}$ & $\begin{array}{l}43.13 * * \\
(22.18) \\
{[33.70]}\end{array}$ \\
\hline Parent has bachelor's degree & $\begin{array}{c}-0.11 \\
(0.07) \\
{[-0.04]}\end{array}$ & $\begin{array}{c}93.04 * * * \\
(14.61) \\
{[29.62]}\end{array}$ & $\begin{array}{c}-16.39 * * \\
(8.35)\end{array}$ & $\begin{array}{c}-29.08 * * * \\
(10.69) \\
{[-22.33]}\end{array}$ \\
\hline Single-parent household & $\begin{array}{c}-0.04 \\
(0.08) \\
{[-0.02]}\end{array}$ & $\begin{array}{l}-18.19 \\
(16.14) \\
{[-5.51]}\end{array}$ & $\begin{array}{c}3.99 \\
(8.87)\end{array}$ & $\begin{array}{c}-16.04 \\
(11.39) \\
{[-12.31]}\end{array}$ \\
\hline Black & $\begin{array}{c}-0.51 * * * \\
(0.12) \\
{[-0.16]}\end{array}$ & $\begin{array}{c}-121.07 * * * \\
(29.87) \\
{[-30.60]}\end{array}$ & $\begin{array}{c}-13.32 \\
(14.35)\end{array}$ & $\begin{array}{c}-30.95 \\
(18.25) \\
{[-23.42]}\end{array}$ \\
\hline Hispanic & $\begin{array}{c}-0.31 * * * \\
(0.10) \\
{[-0.10]}\end{array}$ & $\begin{array}{c}-63.02 * * * \\
(22.26) \\
{[-18.40]}\end{array}$ & $\begin{array}{c}-15.24 \\
(12.05)\end{array}$ & $\begin{array}{c}-16.68 \\
(15.34) \\
{[-12.85]}\end{array}$ \\
\hline Siblings under age 15 & $\begin{array}{c}0.04 \\
(0.04) \\
{[0.01]}\end{array}$ & $\begin{array}{c}-1.56 \\
(7.27) \\
{[-0.48]}\end{array}$ & $\begin{array}{c}1.98 \\
(4.08)\end{array}$ & $\begin{array}{l}-2.37 \\
(5.25) \\
{[-1.84]}\end{array}$ \\
\hline Sigma & & $\begin{array}{c}213.77 * * * \\
(10.63)\end{array}$ & $\begin{array}{c}151.51^{* * *} \\
(5.40)\end{array}$ & $\begin{array}{c}191.40^{* * *} \\
(7.55)\end{array}$ \\
\hline Rho_Employed_Homework & $\begin{array}{c}0.33^{* * *} \\
(0.16)\end{array}$ & & & \\
\hline Rho_Employed_Sleep & $\begin{array}{c}0.46^{* * *} \\
(0.10)\end{array}$ & & & \\
\hline Rho_Employed_Screen & $\begin{array}{c}0.52^{* * *} \\
(0.09)\end{array}$ & & & \\
\hline Rho_Homework_Sleep & $\begin{array}{c}0.17 * * * \\
(0.06)\end{array}$ & & & \\
\hline Rho_Homework_Screen & $\begin{array}{l}-0.03 \\
(0.07)\end{array}$ & & & \\
\hline Rho_Sleep_Screen & $\begin{array}{c}0.15^{* * *} \\
(0.05)\end{array}$ & & & \\
\hline Log-likelihood & $-24,040.17$ & & & \\
\hline Observations & 1,607 & 1,607 & 1,607 & 1,607 \\
\hline
\end{tabular}

Observations 1,607 1,607

Standard errors are in parentheses. Marginal effects are in brackets. Reported marginal effects are averages of individual marginal effects rather than effects calculated at the average of the explanatory variables. They are for discrete changes in the indicator variable. For the Tobit model, marginal effects are calculated for the unconditional expected value. Regressions also include region, season, and whether the respondent resides in an SMSA. Significance levels: ${ }^{* * *} \mathrm{p}<0.01,{ }^{* *} \mathrm{p}<0.05,{ }^{*} \mathrm{p}<0.1$. 
Table 6. Effects of Working on Time Use on a School Day: Models Estimated Jointly

\begin{tabular}{|c|c|c|c|c|}
\hline & $(1)$ & $(2)$ & (3) & $(4)$ \\
\hline VARIABLES & Probit Worked & Tobit Homework & $\begin{array}{c}\text { Non-censored } \\
\text { Sleep }\end{array}$ & Tobit Screen \\
\hline Worked on diary day & & $\begin{array}{c}-135.77 * * * \\
(22.48) \\
{[-49.99]}\end{array}$ & $\begin{array}{l}165.32 * * * \\
(14.96)\end{array}$ & $\begin{array}{c}-44.26 \\
(35.30) \\
{[-31.82]}\end{array}$ \\
\hline State unemployment rate & $\begin{array}{c}-0.06^{* *} \\
(0.03) \\
{[-0.02]}\end{array}$ & & & \\
\hline Female & $\begin{array}{c}0.08 \\
(0.08) \\
{[0.02]}\end{array}$ & $\begin{array}{c}32.45^{* * *} \\
(7.35) \\
{[16.79]}\end{array}$ & $\begin{array}{c}-12.50^{* *} \\
(7.62)\end{array}$ & $\begin{array}{c}-23.30 * * * \\
(8.00) \\
{[-17.56]}\end{array}$ \\
\hline Age 16 & $\begin{array}{l}0.44 * * * \\
(0.12) \\
{[0.08]}\end{array}$ & $\begin{array}{c}6.74 \\
(9.74) \\
{[3.52]}\end{array}$ & $\begin{array}{l}-24.19 * * \\
(10.06)\end{array}$ & $\begin{array}{r}5.24 \\
(10.91) \\
{[4.01]}\end{array}$ \\
\hline Age 17 & $\begin{array}{l}0.53^{* * *} \\
(0.12) \\
{[0.10]}\end{array}$ & $\begin{array}{r}0.94 \\
(10.05) \\
{[0.48]}\end{array}$ & $\begin{array}{l}-29.52 * * * \\
(10.29)\end{array}$ & $\begin{array}{c}-6.33 \\
(11.27) \\
{[-4.77]}\end{array}$ \\
\hline Age 18 & $\begin{array}{l}0.93^{* * *} \\
(0.15) \\
{[0.21]}\end{array}$ & $\begin{array}{l}-15.98 \\
(15.45) \\
{[-7.83]}\end{array}$ & $\begin{array}{l}-50.13^{* * *} \\
(14.69)\end{array}$ & $\begin{array}{c}-27.42 \\
(17.25) \\
{[-20.03]}\end{array}$ \\
\hline Parent has bachelor's degree & $\begin{array}{c}-0.02 \\
(0.09) \\
{[-0.00]}\end{array}$ & $\begin{array}{c}37.09 * * * \\
(7.99) \\
{[19.63]}\end{array}$ & $\begin{array}{l}-8.45 \\
(8.40)\end{array}$ & $\begin{array}{c}-5.97 \\
(8.85) \\
{[-4.49]}\end{array}$ \\
\hline Single-parent household & $\begin{array}{c}-0.09 \\
(0.09) \\
{[-0.02]}\end{array}$ & $\begin{array}{c}-24.49 * * * \\
(8.67) \\
{[-12.28]}\end{array}$ & $\begin{array}{l}12.31 \\
(8.87)\end{array}$ & $\begin{array}{c}2.96 \\
(9.31) \\
{[2.24]}\end{array}$ \\
\hline Black & $\begin{array}{c}-0.10 \\
(0.14) \\
{[-0.02]}\end{array}$ & $\begin{array}{l}-16.18 \\
(13.46) \\
{[-8.08]}\end{array}$ & $\begin{array}{r}25.59 * \\
(13.38)\end{array}$ & $\begin{array}{l}28.75^{* *} \\
(14.01) \\
{[22.23]}\end{array}$ \\
\hline Hispanic & $\begin{array}{l}-0.35^{* * *} \\
(0.13) \\
{[-0.07]}\end{array}$ & $\begin{array}{c}-4.71 \\
(11.20) \\
{[-2.43]}\end{array}$ & $\begin{array}{c}27.47 * * \\
(11.57)\end{array}$ & $\begin{array}{r}12.92 \\
(12.26) \\
{[9.78]}\end{array}$ \\
\hline Siblings under age 15 & $\begin{array}{c}0.07 \\
(0.04) \\
{[0.02]}\end{array}$ & $\begin{array}{c}-7.09 * \\
(4.04) \\
{[-3.70]}\end{array}$ & $\begin{array}{c}1.89 \\
(4.17)\end{array}$ & $\begin{array}{c}-15.88 * * * \\
(4.41) \\
{[-12.11]}\end{array}$ \\
\hline Sigma & & $\begin{array}{c}125.26^{* * * *} \\
(4.34)\end{array}$ & $\begin{array}{c}143.26 * * * \\
(3.57)\end{array}$ & $\begin{array}{c}146.34 * * * \\
(3.26)\end{array}$ \\
\hline Rho_Worked_Homework & $\begin{array}{l}0.42 * * * \\
(0.08)\end{array}$ & & & \\
\hline Rho_Worked_Sleep & $\begin{array}{l}-0.77 * * * \\
(0.03)\end{array}$ & & & \\
\hline Rho_Worked_Screen & $\begin{array}{l}-0.09 \\
(0.12)\end{array}$ & & & \\
\hline Rho_Homework_Sleep & $\begin{array}{l}-0.24 * * * \\
(0.04)\end{array}$ & & & \\
\hline Rho_Homework_Screen & $\begin{array}{l}-0.29 * * * \\
(0.04)\end{array}$ & & & \\
\hline Rho_Sleep_Screen & $\begin{array}{l}0.07^{* *} \\
(0.05)\end{array}$ & & & \\
\hline $\begin{array}{l}\text { Log-likelihood } \\
\text { Observations }\end{array}$ & $\begin{array}{c}-21,761.18 \\
1,420\end{array}$ & 1,420 & 1,420 & 1,420 \\
\hline
\end{tabular}

Standard errors are in parentheses. Marginal effects are in brackets. Reported marginal effects are averages of individual marginal effects rather than effects calculated at the average of the explanatory variables. They are for discrete changes in the indicator variable. For the Tobit model, marginal effects are calculated for the unconditional expected value.

Regressions also include region, season, and whether the respondent resides in an SMSA. Significance levels: *** $\mathrm{p}<0.01,{ }^{* *} \mathrm{p}<0.05,{ }^{*} \mathrm{p}<0.1$. 
Table 7. Effects of Working on Time Use on a Non-School Days: Models Estimated Jointly

\begin{tabular}{|c|c|c|c|c|}
\hline & $(1)$ & $(2)$ & (3) & (4) \\
\hline VARIABLES & Probit Worked & Tobit Homework & $\begin{array}{c}\text { Non-censored } \\
\text { Sleep } \\
\end{array}$ & Tobit Screen \\
\hline Worked on diary day & & $\begin{array}{c}-192.99 * * * \\
(53.02) \\
{[-42.72]}\end{array}$ & $\begin{array}{c}-204.37 * * * \\
(24.40)\end{array}$ & $\begin{array}{c}-255.57 * * * \\
(28.94) \\
{[-163.17]}\end{array}$ \\
\hline State unemployment rate & $\begin{array}{l}-0.08 * * \\
(0.03) \\
{[-0.02]}\end{array}$ & & & \\
\hline Female & $\begin{array}{c}-0.04 \\
(0.08) \\
{[-0.01]}\end{array}$ & $\begin{array}{l}80.53^{* * *} \\
(13.84) \\
{[25.45]}\end{array}$ & $\begin{array}{l}-6.74 \\
(7.64)\end{array}$ & $\begin{array}{c}-33.46 * * * \\
(9.43) \\
{[-26.37]}\end{array}$ \\
\hline Age 16 & $\begin{array}{l}0.49 * * * \\
(0.12) \\
{[0.08]}\end{array}$ & $\begin{array}{l}47.30 * * \\
(19.80) \\
{[13.82]}\end{array}$ & $\begin{array}{c}10.55 \\
(10.36)\end{array}$ & $\begin{array}{c}-4.02 \\
(12.73) \\
{[-3.17]}\end{array}$ \\
\hline Age 17 & $\begin{array}{l}0.72 * * * \\
(0.12) \\
{[0.14]}\end{array}$ & $\begin{array}{l}68.16^{* * *} \\
(21.80) \\
{[20.94]}\end{array}$ & $\begin{array}{c}4.30 \\
(10.89)\end{array}$ & $\begin{array}{c}-1.14 \\
(13.39) \\
{[-0.90]}\end{array}$ \\
\hline Age 18 & $\begin{array}{l}0.67 * * * \\
(0.15) \\
{[0.13]}\end{array}$ & $\begin{array}{c}30.74 \\
(28.87) \\
{[8.62]}\end{array}$ & $\begin{array}{c}7.44 \\
(14.85)\end{array}$ & $\begin{array}{r}5.52 \\
(18.37) \\
{[4.38]}\end{array}$ \\
\hline Parent has bachelor's degree & $\begin{array}{l}-0.16^{* *} \\
(0.08) \\
{[-0.04]}\end{array}$ & $\begin{array}{l}88.02^{* * *} \\
(14.85) \\
{[28.53]}\end{array}$ & $\begin{array}{c}-19.06 * * \\
(8.35)\end{array}$ & $\begin{array}{l}-31.23 * * * \\
(10.31) \\
{[-24.51]}\end{array}$ \\
\hline Single-parent household & $\begin{array}{c}-0.04 \\
(0.09) \\
{[-0.01]}\end{array}$ & $\begin{array}{l}-19.59 \\
(16.37) \\
{[-6.06]}\end{array}$ & $\begin{array}{c}3.91 \\
(8.90)\end{array}$ & $\begin{array}{c}-15.54 \\
(10.98) \\
{[-12.19]}\end{array}$ \\
\hline Black & $\begin{array}{c}-0.32 * * \\
(0.14) \\
{[-0.06]}\end{array}$ & $\begin{array}{c}-115.04 * * * \\
(28.33) \\
{[-30.25]}\end{array}$ & $\begin{array}{c}-0.12 \\
(13.45)\end{array}$ & $\begin{array}{c}-7.73 \\
(16.60) \\
{[-6.07]}\end{array}$ \\
\hline Hispanic & $\begin{array}{c}-0.20^{*} \\
(0.12) \\
{[-0.04]}\end{array}$ & $\begin{array}{l}-61.33 * * * \\
(21.80) \\
{[-18.60]}\end{array}$ & $\begin{array}{l}-10.18 \\
(11.70)\end{array}$ & $\begin{array}{c}-6.31 \\
(14.40) \\
{[-4.96]}\end{array}$ \\
\hline Siblings under age 15 & $\begin{array}{c}-0.04 \\
(0.04) \\
{[-0.01]}\end{array}$ & $\begin{array}{c}-5.47 \\
(7.34) \\
{[-1.74]}\end{array}$ & $\begin{array}{l}-2.18 \\
(4.06)\end{array}$ & $\begin{array}{c}-8.36 \\
(5.04) \\
{[-6.62]}\end{array}$ \\
\hline Sigma & & $\begin{array}{l}219.18^{* * *} \\
(11.39)\end{array}$ & $\begin{array}{c}152.06^{* * *} \\
(4.01)\end{array}$ & $\begin{array}{c}184.55^{* * * *} \\
(4.88)\end{array}$ \\
\hline Rho_Worked_Homework & $\begin{array}{l}0.49 * * * \\
(0.12)\end{array}$ & & & \\
\hline Rho_Worked_Sleep & $\begin{array}{l}0.56^{* * *} \\
(0.07)\end{array}$ & & & \\
\hline Rho_Worked_Screen & $\begin{array}{l}0.48^{* * *} \\
(0.07)\end{array}$ & & & \\
\hline Rho_Homework_Sleep & $\begin{array}{l}0.20^{* * *} \\
(0.05)\end{array}$ & & & \\
\hline Rho_Homework_Screen & $\begin{array}{l}-0.02 \\
(0.05)\end{array}$ & & & \\
\hline Rho_Sleep_Screen & $\begin{array}{l}0.12 * * * \\
(0.03)\end{array}$ & & & \\
\hline $\begin{array}{l}\text { Log-likelihood } \\
\text { Observations }\end{array}$ & $\begin{array}{c}-23,713.55 \\
1,607\end{array}$ & 1,607 & 1,607 & 1,607 \\
\hline
\end{tabular}

Standard errors are in parentheses. Marginal effects are in brackets. Reported marginal effects are averages of individual marginal effects rather than effects calculated at the average of the explanatory variables. They are for discrete changes in the indicator variable. For the Tobit model, marginal effects are calculated for the unconditional expected value.

Regressions also include region, season, and whether the respondent resides in an SMSA. Significance levels: *** $\mathrm{p}<0.01, * * \mathrm{p}<0.05, * \mathrm{p}<0.1$. 
Table 8. The Effects of Employment/Working on Time Use for 16- to 18-year-olds: Models Jointly Estimated

\begin{tabular}{cccc|ccc} 
& \multicolumn{3}{c}{ School day sample } & \multicolumn{3}{c}{ Non-school day sample } \\
\cline { 2 - 7 } & $\begin{array}{c}\text { Tobit } \\
\text { Homework }\end{array}$ & $\begin{array}{c}\text { Non-censored } \\
\text { Sleep }\end{array}$ & $\begin{array}{c}\text { Tobit } \\
\text { Screen }\end{array}$ & $\begin{array}{c}\text { Tobit } \\
\text { Homework }\end{array}$ & $\begin{array}{c}\text { Non- } \\
\text { censored } \\
\text { Sleep }\end{array}$ & $\begin{array}{c}\text { Tobit } \\
\text { Screen }\end{array}$ \\
\hline Employed & $-94.85^{* * *}$ & $161.98^{* * *}$ & -71.89 & $-124.71^{* *}$ & $-193.74^{* * *}$ & $-254.11^{* * *}$ \\
previous & $(36.45)$ & $(21.12)$ & $(45.66)$ & $(61.82)$ & $(30.77)$ & $(37.88)$ \\
week & {$[-44.39]$} & & {$[-52.36]$} & {$[-37.29]$} & & {$[-183.31]$} \\
Log likelihood & $-16,140.93$ & & & $-17,856.75$ & & $-268.37 * * *$ \\
Worked & $-138.78 * * *$ & $172.44^{* * *}$ & -50.37 & $-238.85^{* * *}$ & $-234.87 * * *$ & $(30.64)$ \\
on diary day & $(25.31)$ & $(17.03)$ & $(41.88)$ & $(56.02)$ & $(23.31)$ & {$[-167.64]$} \\
Log likelihood & $-15,891.14$ & & {$[-35.88]$} & {$[-54.88]$} & & 1,193 \\
Observations & 1,041 & 1,041 & 1,041 & 1,193 & 1,193 & -17.643 .30 \\
\hline
\end{tabular}

Standard errors are in parentheses. Marginal effects are in brackets. Reported marginal effects are averages of individual marginal effects rather than effects calculated at the average of the explanatory variables. They are for discrete changes in the indicator variable. For the Tobit model, marginal effects are calculated for the unconditional expected value. Significance levels: *** $\mathrm{p}<0.01, * * \mathrm{p}<0.05, * \mathrm{p}<0.1$ 
Table 9. The Effects of Employment/Working on Alternative Time Use Definitions

\begin{tabular}{ccccc|cccc}
\hline & \multicolumn{4}{c}{ School day sample } & \multicolumn{4}{c}{ Non-school day sample } \\
\cline { 2 - 8 } & $\begin{array}{c}\text { Homework / } \\
\text { Extracurricular }\end{array}$ & $\begin{array}{c}\text { Homework/ } \\
\text { Extra/Sports }\end{array}$ & $\begin{array}{c}\text { Night } \\
\text { sleep }\end{array}$ & $\begin{array}{c}\text { Screen/ } \\
\text { games }\end{array}$ & $\begin{array}{c}\text { Homework/ } \\
\text { Extracurricular }\end{array}$ & $\begin{array}{c}\text { Homework/ } \\
\text { Extra/Sports }\end{array}$ & $\begin{array}{c}\text { Night } \\
\text { sleep }\end{array}$ & $\begin{array}{c}\text { Screen/ } \\
\text { games }\end{array}$ \\
\hline Employed & $-159.80^{* * *}$ & $-165.34^{* * *}$ & -48.50 & 6.03 & $-118.65^{* *}$ & $-162.14^{* *}$ & $-133.14^{* * *}$ & $-286.33^{* * *}$ \\
previous & $(34.66)$ & $(46.60)$ & $(149.21)$ & $(50.49)$ & $(58.00)$ & $(73.99)$ & $(39.24)$ & $(36.17)$ \\
week & {$[-74.59]$} & {$[-99.82]$} & & {$[4.70]$} & {$[-36.11]$} & {$[-79.86]$} & $-212.20]$ \\
Log likelihood & $-22,417.61$ & $-23,665.69$ & $-22,087.53$ & $-23,589.26$ & $-24,332.70$ & $-26,684.18$ & $-24,079.35$ & $-24,369.14$ \\
\hline Worked & $-142.47 * * *$ & $-215.04 * * *$ & $-77.26 * *$ & 9.69 & $-216.35^{* * *}$ & $-265.94^{* * *}$ & $-151.80^{* * *}$ & $-164.91^{* * *}$ \\
on diary day & $(28.69)$ & $(24.43)$ & $(35.77)$ & $(46.32)$ & $(59.54)$ & $(46.04)$ & $(41.61)$ & $(37.36)$ \\
& {$[-56.45]$} & {$[-103.52]$} & & {$[7.59]$} & {$[-50.85]$} & {$[-101.28]$} & \\
Log likelihood & $-22,088.16$ & $-23,304.36$ & $-21,749.47$ & $-23,239.55$ & $-24,005.32$ & $-26,342.07$ & $-23,762.45$ & $-26,359.69$ \\
\hline Observations & 1,420 & 1,420 & 1,417 & 1,420 & 1,607 & 1,607 & 1,604 & 1,607 \\
\hline
\end{tabular}

Note: Standard errors are in parentheses. Marginal effects are in brackets. Reported marginal effects are averages of individual marginal effects rather than effects calculated at the average of the explanatory variables. They are for discrete changes in the indicator variable. For the Tobit model, marginal effects are calculated for the unconditional expected value. Significance levels: $* * *$ $\mathrm{p}<0.01, * * \mathrm{p}<0.05, * \mathrm{p}<0.1$. 
Table 10. Model Including Both Employment Measures

\begin{tabular}{|c|c|c|c|}
\hline & Tobit Homework & Non-censored Sleep & Tobit Screen \\
\hline \multirow[t]{3}{*}{ Employed previous week } & 3.99 & -15.68 & $-60.69 * *$ \\
\hline & $(42.09)$ & $(26.47)$ & $(25.57)$ \\
\hline & {$[1.58]$} & & {$[-45.91]$} \\
\hline \multirow[t]{3}{*}{ Employed previous week* worked on diary day } & -5.03 & $-46.27 * *$ & $-139.61 * * *$ \\
\hline & $(42.34)$ & $(23.02)$ & $(29.27)$ \\
\hline & {$[-1.97]$} & & {$[-94.30]$} \\
\hline Log likelihood & $-46,972.81$ & & \\
\hline Number of observations & 3,027 & 3,027 & 3,027 \\
\hline
\end{tabular}


Table 11. Predicted hours of diary day sleep and screen time based upon employment status, by school-day status

\begin{tabular}{lcc|cc}
\hline & \multicolumn{2}{c|}{ Sleep on diary day } & \multicolumn{2}{c}{ Screen and games } \\
\cline { 2 - 5 } & Schooldays & Non-school days & Schooldays & Non-school days \\
\hline Employed & 10.16 & 8.77 & $\mathbf{2 . 1 6}$ & 0.25 \\
Not Employed & 7.7 & 11.32 & $\mathbf{2 . 0 8}$ & $\mathbf{5 . 0 6}$ \\
Working & 10.93 & 7.53 & 2.23 & 1.05 \\
Not Working & $\mathbf{8 . 1 5}$ & 10.93 & $\mathbf{2 . 0 9}$ & $\mathbf{3 . 8 1}$ \\
\hline
\end{tabular}

Note: Hours in bold are outside the recommended ranges of the National Sleep Foundation and the American Academy of Pediatrics for sleep and screen time, respectively. 


\section{DATA APPENDIX}

Table A1. Time Use Variables and ATUS codes

\begin{tabular}{|c|c|c|}
\hline Time Variable & Activities & Codes \\
\hline Paid Work & $\begin{array}{l}\text { Working at main or other } \\
\text { job }\end{array}$ & $0501 x x$ \\
\hline Homework & $\begin{array}{l}\text { Research/homework for a } \\
\text { class for degree }\end{array}$ & 060301 \\
\hline Extracurricular & $\begin{array}{l}\text { Classes for personal } \\
\text { interest, extracurricular } \\
\text { school activities (except } \\
\text { sports), taking other not } \\
\text { classified classes, } \\
\text { homework for a class } \\
\text { taken for personal interest }\end{array}$ & $060102,060199,0602,060302$ \\
\hline Sports & $\begin{array}{l}\text { Participating in sports, } \\
\text { exercise or recreation }\end{array}$ & 1301 \\
\hline Screen & $\begin{array}{l}\text { Watching television and } \\
\text { movies, using the } \\
\text { computer for leisure } \\
\text { (except games), surfing the } \\
\text { web, participating in a chat } \\
\text { room }\end{array}$ & 1230303,120308 \\
\hline Games & $\begin{array}{l}\text { Playing computer and } \\
\text { board games and cards }\end{array}$ & 120307 \\
\hline Sleep & sleeping & 0101xx \\
\hline
\end{tabular}

Note: The codes correspond to the variables TUTIER1CODE, TUTIER2CODE, and TUTIER3Code in the ATUS activity file. 
Table A2. Selected Descriptive Statistics for Covariates

\begin{tabular}{lcc}
\hline Variable & Mean & $\begin{array}{c}\text { Standard } \\
\text { Deviation }\end{array}$ \\
\hline Number of siblings under age 15 & 0.74 & 1.20 \\
State monthly unemployment rate & 5.26 & 1.43 \\
Female & 0.49 & \\
Age 15 & 0.25 & \\
Age 16 & 0.33 \\
Age 17 & 0.31 & \\
Age 18 & 0.12 \\
School day & 0.70 & \\
Non-black, non-Hispanic & 0.68 & \\
Black & 0.14 & \\
Hispanic & 0.18 & \\
Single parent household & 0.25 & \\
Parent has bachelor's degree & 0.38 & \\
Resides in SMSA & 0.83 & \\
\hline Number of Observations & 3,027 &
\end{tabular}

